\title{
Reoquarfia
}

Malaysian Tournal of Society and Space

\section{Pandemik COVID-19 dan keganasan rumah tangga: Suatu tinjauan semasa Perintah Kawalan Pergerakan di Malaysia}

\author{
Muhammad Wafi Ramli, Sharifah Rohayah Sheikh Dawood, Sofia Haminah Mohd Som \\ Unit Geoinformatik, Bahagian Geografi, Pusat Pengajian Ilmu Kemanusiaan, \\ Universiti Sains Malaysia \\ Correspondence: Sharifah Rohayah Sheikh Dawood (email: sdawood@usm.my)
}

Received: 15 January 2021; Accepted: 11 August 2021; Published: 27 August 2021

\begin{abstract}
Abstrak
Sejak pandemik COVID-19 menular aktif dalam negara, kerajaan telah melaksanakan perintah kawalan pergerakan (PKP) terhadap seluruh masyarakat untuk mengawal penyebaran virus. Impak pelaksanaan PKP telah mewujudkan pelbagai krisis sosial terutama isu keganasan rumah tangga (KRT). Justeru, artikel ini bertujuan untuk meninjau impak PKP terhadap isu KRT dari sudut faktor penyumbang dan peranan pihak pemegang taruh dalam menangani isu ini semasa PKP. Kajian ini melibatkan pengumpulan data sekunder dan analisis kandungan. Hasil kajian mendapati bahawa sepanjang tempoh PKP, terdapat enam faktor penyumbang kes KRT, iaitu kekangan ruang persekitaran, pengaruh dadah dan alkohol, kebergantungan pada pasangan, ketiadaan sistem sokongan yang kukuh, konflik dalaman individu dan tiada ilmu tentang KRT. Terdapat beberapa agensi kerajaan dan pertubuhan bukan kerajaan (NGO) yang cakna menjalankan tanggungjawab mereka membantu dari segi kewangan, kempen, kaunseling dan perlindungan berhubung isu ini semasa PKP. Kajian ini dirujuk penting dalam memberi gambaran berkenaan isu KRT yang berlaku semasa PKP khususnya di Malaysia dan diharapkan agar pihak pemegang taruh dapat merangka strategi yang holistik bagi menangani isu KRT yang semakin kritikal di negara ini.
\end{abstract}

Kata kunci: Keganasan rumah tangga, Malaysia, pandemik COVID-19, pemegang taruh, perintah kawalan pergerakan

\section{The COVID-19 pandemic and domestic violence: A review during the Movement Control Order in Malaysia}

\begin{abstract}
Since the COVID-19 pandemic is actively spreading in the country, the government has implemented a movement control order (MCO) on the entire society to control the spread of the
\end{abstract}


virus. The impact of the implementation of $\mathrm{MCO}$ has created various social crises, especially the issue of domestic violence (DV). Thus, this article aims to examine the impact of MCO on the issue of DV in terms of contributing factors and the role of stakeholders in addressing this issue during MCO. The study involved secondary data collection and content analysis. Our findings indicate that during the MCO period, there are six contributing factors to DV, namely environmental constraints, drug and alcohol influence, dependence on spouses, lack of strong support system, individual internal conflict, and lack of knowledge about DV. There are several government agencies and non-governmental organizations (NGOs) that have concern and carry out their responsibilities to assist in terms of financial, campaigns, counselling, and protection on these issues during the MCO. This study is referred vital in giving an overview of the DV issues that occurred during the MCO, especially in Malaysia and it is hoped that relevant stakeholders can further formulate a holistic strategy to address and combat the DV issue that is increasingly getting critical in this country.

Keywords: Domestic violence, Malaysia, COVID-19 pandemic, stakeholders, movement control order

\section{Pengenalan}

Pada 30 Januari 2020, Pertubuhan Kesihatan Sedunia (WHO) telah mengisytiharkan COVID-19 sebagai darurat kesihatan awam yang menjadi perhatian antarabangsa dan pada 11 Mac 2020, ia diisytiharkan sebagai pandemik global kerana terus merebak dengan cepat ke seluruh dunia (Liu et al., 2020). Kebanyakan negara terkesan dengan pandemik COVID-19 termasuk Malaysia yang merekodkan kes pertama pada bulan Januari 2020 dan angka jangkitan meningkat pada bulanbulan seterusnya di kebanyakan negeri (Dawood et al., 2020; Hamid et al., 2021; Ramli \& Jamri, 2021). Hal ini secara tidak langsung memberi tekanan kepada kerajaan untuk melaksanakan beberapa strategi bagi mengekang penyebaran virus di dalam negara. Penutupan sebilangan besar sektor dalam negara terutama ekonomi telah mengakibatkan implikasi psikososial berlaku dalam kalangan individu. Kehilangan pekerjaan dan sumber kewangan ketika pandemik merupakan situasi yang benar-benar berlaku bagi sebilangan besar penduduk di kebanyakan negara yang mengundang kepada berlakunya krisis sosial dalam kalangan masyarakat.

Berikutan pandemik COVID-19 yang melanda dunia, kebanyakan negara yang melaksanakan perintah berkurung, kuarantin atau sekat keluar masuk (lockdown) telah berhadapan dengan pelbagai cabaran besar seperti peningkatan masalah keganasan rumah tangga (KRT). Malaysia tidak terkecuali dalam mengalami isu KRT ketika pandemik yang menunjukkan statistik peningkatan kes ketika PKP dilaksanakan. Mittal \& Singh (2020) menyatakan bahawa perintah berkurung telah menyebabkan perubahan gaya hidup individu yang drastik saban hari. Perintah berkurung juga memburukkan lagi keadaan golongan rentan terutama wanita yang sudah sedia bermasalah dengan kes-kes keganasan dan tekanan ekonomi semasa menghadapi krisis pandemik.

Menurut Ertan et al. (2020), pada masa kini, terdapat kelompangan dan kekangan data berhubung kes KRT semasa pandemik COVID-19 dan kajian berkenaannya dalam konteks pandemik COVID-19 masih lagi berada di peringkat awal. Goh et al. (2020) menyarankan bahawa adalah penting untuk mengekang isu peningkatan KRT ketika pandemik dan perlunya langkahlangkah yang berkesan diambil untuk mengatasinya. Kumar (2020) juga mencadangkan perlunya kajian yang lebih lanjut untuk memahami faktor dan kedinamikan isu KRT ketika pandemik. 
Justeru, melalui kelompangan, saranan dan cadangan tersebut, kajian ini bertujuan untuk mengkaji impak PKP terhadap isu KRT yang berlaku di Malaysia dari sudut faktor penyumbang dan peranan pihak pemegang taruh dalam menangani isu ini.

\section{Kajian literatur}

Menurut Pertubuhan Bangsa-Bangsa Bersatu (UN, 2020a), KRT disebut sebagai "domestic violence" atau "intimate partner violence", yang boleh ditakrifkan sebagai satu corak tingkah laku dalam sesuatu hubungan untuk menunjukkan atau memperoleh kuasa dan kawalan terhadap pasangan rapat. Penderaan adalah tindakan atau ancaman berbentuk fizikal, seksual, emosi atau psikologi yang mempengaruhi orang lain. Hal ini termasuklah tingkah laku cubaan untuk menakutkan, memanipulasi, mencederakan, memalukan, menuduh, mengancam dan melukakan seseorang. Flury et al. (2010) mentakrifkan KRT sebagai satu ancaman keganasan berbentuk fizikal, psikologi dan emosi. Misalnya, apa jua bentuk paksaan terhadap individu dengan niat untuk mencederakan, serta mengenakan kuasa atau kawalan terhadap mereka. Pihak yang mengancam biasanya berada dalam "persekitaran domestik" si mangsa, yakni boleh jadi pasangan rapat, suami atau isteri, bekas pasangan, ahli keluarga, kawan atau kenalan.

Berdasarkan definisi oleh Jabatan Kebajikan Masyarakat Malaysia (JKM, 2020), KRT merujuk kepada satu bentuk kelakuan, iaitu dengan sengaja atau cuba meletakkan mangsa dalam situasi ketakutan dan mencederakan mangsa dari aspek fizikal. Malah, ia juga melibatkan perbuatan memaksa atau mengancam mangsa dari sudut seksual atau lain-lain yang membolehkan mangsa memiliki hak untuk tidak akur terhadap perbuatan tersebut. Selain itu, KRT juga merujuk kepada perbuatan menahan atau mengurung mangsa tanpa kerelaannya. Bahkan, perbuatan khianat atau merosakkan harta benda mangsa dengan niat bagi menimbulkan rasa sedih dan segala bentuk penderaan secara psikologi turut dikategorikan sebagai KRT.

UN (2020b) menyatakan bahawa wanita dan gadis muda mempunyai risiko yang tinggi terhadap KRT dan keganasan pasangan intim (intimate partner violence) semasa pandemik. KRT dalam kalangan wanita merupakan fenomena yang serius kerana mendatangkan kesan yang berbahaya secara fizikal dan mental (Na'aim et al., 2019). Rauhus et al. (2020) menyatakan KRT berlaku dalam pelbagai bentuk yang merangkumi penderaan fizikal, emosi, intimidasi, paksaan seksual, penganiayaan kewangan dan digital. Menurut WHO (2017), keganasan terhadap wanita telah dianggap sebagai masalah kesihatan awam yang mana 1 dalam 3 wanita (35\%) di seluruh dunia mengalami keganasan dan ini boleh menjadi lebih ketara dengan batasan atau kekangan terhadap akses perkhidmatan kesihatan dan perkhidmatan lain.

Menurut Goh et al. (2020), polisi perintah berkurung menyumbang kepada peningkatan kerentanan terhadap kesihatan mental. Kesan psikososial yang serius seperti ketakutan, kekecewaan dan kebosanan dikaitkan dengan gejala trauma, kebimbangan dan kemurungan semasa tempoh perintah berkurung (Brooks et al., 2020). Kesemua ini mempunyai manisfestasi dari segi tingkah laku dan psikologi yang boleh membawa kepada tekanan, pergaduhan, konflik, kemarahan dan juga keganasan (Kumar, 2020). Secara umum, wanita mengalami keganasan daripada pasangan mereka dan menuntut sokongan psikologi (Silverio-Murillo \& de la Miyar, 2020). Menurut WHO (2020a), keganasan menyebabkan risiko yang serius untuk kesihatan wanita semasa darurat dan cenderung meningkat semasa pandemik. Malik dan Naeem (2020) menegaskan ketika isolasi sosial dan penjarakan sosial diamalkan, terdapat peningkatan risiko keganasan, penderaan, eksploitasi, dan pengabaian yang berlaku terhadap wanita. 
Boserup et al. (2020) menyatakan perintah berkurung boleh menyebabkan bencana bagi individu yang hidupnya terganggu disebabkan oleh KRT. Ertan et al. (2020) menegaskan bahawa perintah berkurung mungkin telah mewujudkan persekitaran berisiko tinggi untuk kejadian KRT dengan peningkatan tekanan berkaitan pandemik dan keterbatasan akses kepada sumber perlindungan. Di kebanyakan negara, perintah berkurung menyebabkan keterbatasan akses kepada dunia luar yang akan memberi kesan drastik terhadap kemampuan individu untuk meminta pertolongan (Vincent, 2020). Perintah berkurung secara tidak langsung meningkatkan beban terhadap golongan wanita untuk menguruskan hal rumah tangga. Walaupun wanita sudah melakukan sebahagian besar tanggungjawab sebegitu sebelum wujudnya pandemik COVID-19, namun krisis pandemik ini mengakibatkan beban yang lebih dramatik (Power, 2020). Kumar (2020) menegaskan bahawa perintah berkurung telah meningkatkan beban wanita untuk memasak, menyediakan makanan, dan menguruskan tugas rumah tangga dan ahli keluarga yang berada di rumah. Secara ironi, istilah "lebih aman di rumah" telah terbukti berbahaya bagi sebilangan besar wanita ketika isu KRT semakin meningkat (Kofman \& Garfin, 2020).

Selain itu, perintah berkurung mempunyai kesan terhadap wanita dan anak-anak untuk mudah terdedah dengan keganasan semasa menghabiskan masa bersama di rumah (WHO, 2020b). Wanita dalam hubungan teraniaya (abusive relationship) mungkin lebih terdedah kepada keganasan, begitu juga dengan anak-anak mereka kerana menghabiskan lebih banyak masa bersama keluarga dan menghadapi tekanan tambahan (WHO, 2020c). Ramai wanita dan anakanak yang tinggal bersama pendera semasa perintah berkurung dirujuk sangat berbahaya kerana mereka harus meluangkan masa sepanjang hari bersama pendera dan jauh daripada orang yang dapat memberi pertolongan (Bouillon-Minois et al., 2020; Mazza et al., 2020). Kajian PerezVincent et al. (2020) membuktikan bahawa apabila pasangan wanita berada dalam perintah berkurung, terdapat kecenderungan penderaan yang tinggi berlaku dalam semua bentuk seperti emosi, seksual dan fizikal. Kajian tersebut juga mendapati bahawa pasangan wanita yang berada dalam perintah berkurung akhirnya menghabiskan lebih banyak masa bersama dengan pendera yang mungkin mewujudkan ketegangan atau hanya memberi lebih banyak peluang dan potensi kepada pendera untuk melakukan keganasan.

\section{Bilangan kes KRT global ketika pandemik}

Statistik global menunjukkan kes KRT di kebanyakan negara meningkat sepanjang tempoh pandemik COVID-19 melanda dunia. UN Women (2020a) menyatakan bahawa insiden keganasan terhadap wanita telah meningkat di seluruh dunia sejak perintah berkurung dilaksanakan. Jadual 1 menunjukkan kadar peratusan kes berhubung isu KRT di Singapura, Perancis, Cyprus, Brazil, Argentina, New Zealand, Peru, Sepanyol, China, Taiwan, India, Australia, UK dan USA sejak perintah berkurung berkuat kuasa pada bulan Mac 2020. Sebilangan besar kategori kes KRT yang merekodkan peningkatan adalah melibatkan panggilan talian bantuan. Namun, menurut Campbell (2020), trend global berkenaan laporan KRT yang semakin meningkat mungkin berlanjutan sepanjang pandemik kerana ramai mangsa masih terperangkap dengan pendera dan tidak dapat melaporkan penderaan tersebut. 
Jadual 1: Peratusan kes KRT di luar negara ketika pandemik.

\begin{tabular}{|c|c|c|}
\hline Negara & $\begin{array}{c}\text { Peratusan } \\
\text { kes }\end{array}$ & Kategori \\
\hline Singapura & $33 \%$ & Peningkatan panggilan bantuan untuk KRT. \\
\hline Perancis & $30 \%$ & Peningkatan kes KRT. \\
\hline Cyprus & $30 \%$ & Peningkatan panggilan bantuan untuk KRT. \\
\hline Brazil & $50 \%$ & Peningkatan laporan KRT. \\
\hline Argentina & $25 \%$ & Peningkatan panggilan kecemasan KRT. \\
\hline New Zealand & $20 \%$ & Peningkatan kes KRT. \\
\hline Peru & $48 \%$ & $\begin{array}{l}\text { Peningkatan panggilan bantuan nasional } \\
\text { keganasan terhadap wanita. }\end{array}$ \\
\hline Sepanyol & $47 \%$ & Peningkatan panggilan bantuan untuk KRT. \\
\hline China & $50 \%$ & Laporan peningkatan panggilan KRT. \\
\hline Taiwan & $5 \%$ & Peningkatan kes KRT \\
\hline India & $100 \%$ & $\begin{array}{l}\text { Peningkatan aduan yang berkaitan dengan } \\
\text { keganasan terhadap wanita. }\end{array}$ \\
\hline Australia & $75 \%$ & $\begin{array}{l}\text { Peningkatan carian Google yang berkaitan } \\
\text { dengan KRT }\end{array}$ \\
\hline UK & $25 \%$ & Peningkatan panggilan berkaitan kes KRT. \\
\hline USA & $21-35 \%$ & Peningkatan kes KRT. \\
\hline
\end{tabular}

Sumber: Agüero (2020); Burgen (2020); Das et al. (2020); Johnston (2020); Kagi (2020); Lepla (2020); UN Women (2020b); Vora et al. (2020)

\section{Bilangan kes KRT di Malaysia ketika pandemik}

KRT bukanlah sesuatu isu yang baharu di Malaysia. Ia telah lama berlaku sebelum wujudnya pandemik COVID-19. Namun, ketika PKP mula dilaksanakan pada 18 Mac 2020 hingga 12 Mei 2020, yang mana tempoh PKP ini melibatkan empat fasa, iaitu fasa 1 pada 19 Mac-31 Mac, fasa 2 pada 1 April-14 April, fasa 3 pada 15 April-28 April dan fasa 4 pada 29 April-12 Mei, bilangan kes KRT direkodkan meningkat di kebanyakan negeri sepanjang empat fasa PKP tersebut. Merujuk Jadual 2, kebanyakan negeri merekodkan bilangan kes KRT kecuali Perlis dan Labuan yang menyaksikan tiada sebarang kes direkodkan. Namun, bilangan kes KRT yang tertinggi berlaku adalah di Pulau Pinang, dengan merekodkan sebanyak 80 kes. Kes kedua tertinggi berlaku di Selangor dengan merekodkan sebanyak 70 kes. Diikuti dengan negeri Johor (21 kes), Kuala Lumpur (20 kes), Pahang (13 kes), Perak (12 kes), Kedah (11 kes), Negeri Sembilan dan Sabah (8 kes), Kelantan (5 kes), Melaka dan Terengganu (3 kes), dan Sarawak (1 kes). Secara keseluruhan, sebanyak 255 kes KRT direkodkan berlaku di Malaysia ketika PKP. Angka ini diandaikan akan terus meningkat jika kerajaan Malaysia memanjangkan tempoh PKP. 
Jadual 2: Bilangan kes KRT di Malaysia semasa PKP (18 Mac-12 Mei 2020)

\begin{tabular}{lc} 
Negeri & Bilangan kes \\
\hline Pulau Pinang & 80 \\
Selangor & 70 \\
Johor & 21 \\
Kuala Lumpur & 20 \\
Pahang & 13 \\
Perak & 12 \\
Kedah & 11 \\
Negeri Sembilan & 8 \\
Sabah & 8 \\
Kelantan & 5 \\
Melaka & 3 \\
Terengganu & 3 \\
Sarawak & 1 \\
Perlis & Tiada kes \\
Labuan & Tiada kes \\
Jumlah & $\mathbf{2 5 5}$ \\
\hline
\end{tabular}

Sumber: WCC (2020) \& KPWKM (2020)

\section{Kaedah kajian}

Kajian ini melibatkan kaedah pengumpulan data sekunder dengan menggunakan artikel-artikel akademik, akhbar-akhbar tempatan dan luar negara dalam talian, dan dokumen-dokumen dari laman sesawang rasmi pertubuhan kerajaan, pertubuhan bukan kerajaan (NGO) dan lain-lain organisasi. Pangkalan data seperti Google, Google Scholar dan Scopus digunakan untuk mendapatkan artikel-artikel, akhbar-akhbar, dan dokumen-dokumen yang berkaitan dengan konteks kajian ini. Kata kunci seperti "keganasan rumah tangga' / "domestic violence", "wanita" / "women", "COVID-19", dan "perintah kawalan pergerakan" / "movement control order" / "lockdown" / "quarantine" digunakan sepanjang proses pencarian dan pengumpulan data sekunder. Akhbar-akhbar dan dokumen-dokumen dalam talian yang digunakan adalah ditapis dari bulan Mac 2020 hingga November 2020. Hal ini demikian kerana, tempoh PKP atau perintah berkurung dirujuk bermula pada bulan Mac dan bulan-bulan berikutnya. Berita-berita tempatan dalam talian yang digunakan adalah melalui sumber seperti New Straits Times, BERNAMA, Astro Awani, Utusan Borneo, Buletin Mutiara, MalayMail, myMetro, Sinar Harian dan The Malaysian Insight. Manakala akhbar-akhbar luar negara dalam talian yang digunakan pula adalah seperti The Guardian, New Zealand Media and Entertainment, ABC News Australia, Mondiaal Nieuws, dan Socialist Alternative. Selain itu, dokumen-dokumen rasmi daripada organisasi kerajaan yang digunakan adalah seperti Jabatan Kebajikan Masyarakat (JKM), Kementerian Pembangunan Wanita Keluarga dan Masyarakat (KPWKM) dan Pusat Sumber Komunikasi Risiko dan Media COVID-19 Universiti Sains Malaysia. Manakala dokumen-dokumen rasmi daripada NGO yang digunakan adalah seperti laman sesawang dan Facebook rasmi Pertubuhan Pertolongan Wanita (WAO) dan Pusat Kesedaran Wanita (WCC). Begitu juga dengan dokumen-dokumen daripada lain-lain organisasi yang digunakan seperti UN Women, United Nations dan World Health Organization. Analisis kandungan diaplikasi dalam kajian ini dan huraian data dilakukan secara deskriptif berdasarkan tema-tema yang telah dikenal pasti melalui tinjauan data-data sekunder yang diperoleh. 


\section{Hasil kajian dan perbincangan}

\section{Faktor penyumbang KRT di Malaysia ketika pandemik}

\section{a. Kekangan ruang persekitaran}

Situasi kekangan ruang persekitaran dilihat menjadi salah satu punca berlakunya kes KRT ketika PKP. Kes ini mudah berlaku terhadap mereka yang tinggal di perumahan yang bersaiz kecil seperti rumah pangsa. Hal ini menyebabkan keterbatasan pergerakan individu di rumah tersebut terutama yang mempunyai bilangan isi rumah yang ramai. Keadaan ini secara tidak langsung mencetuskan tekanan dan tiada privasi hidup di rumah tersebut. Privasi yang berkaitan dengan kehidupan rumah tangga boleh menjadi tempat yang berbahaya bagi wanita dan anak-anak kerana pembahagian kerja menimbulkan ketidaksamaan di rumah dan bersama keluarga (Rauhaus et al., 2020). Astro Awani melaporkan bahawa ketika PKP, persekitaran rumah yang tidak kondusif atau sempit menyebabkan berlakunya rasa seolah-olah lemas atau tidak selesa apabila berada di rumah (Gani, 2020). Walaupun KRT boleh berlaku kepada sesiapa sahaja, namun mereka yang hidup dalam keadaan di rumah yang sempit dan tidak kondusif akan menimbulkan rasa tidak tenteram (Ismail \& Sulaiman, 2020). Mazza et al. (2020) berpendapat bahawa mereka yang tinggal di rumah kecil atau tanpa ruang terbuka akan menyebabkan perubahan tekanan yang akan meningkat. Akhbar Utusan Borneo juga menyatakan bahawa mereka yang tinggal lama di rumah ketika PKP akan berasa sedikit tegang dan rimas antara satu sama lain terutama yang mempunyai rumah atau ruang kecil yang mana kanak-kanak agak cenderung untuk membuat bising dan bertengkar apabila berada di dalam rumah sepanjang hari, manakala ibu bapa akan membuat hal masing-masing dan cenderung untuk bertikam lidah sesama mereka (Hamid, 2020).

\section{b. Pengaruh dadah dan alkohol}

Pengaruh dadah dan alkohol juga dilihat menjadi faktor penyumbang kepada kes KRT ketika PKP. Menurut Isaacs et al. (2019), terdapat bukti yang menunjukkan si pendera yang terlibat dengan penggunaan dadah lebih cenderung untuk melakukan KRT. Satu situasi yang dilaporkan berlaku terhadap seorang mangsa yang bernama Hidayah (bukan nama sebenar), yang telah didera oleh bapa kandungnya di Seremban, Negeri Sembilan ketika PKP. Bapanya merupakan seorang penagih dadah sering melemparkan kata-kata kesat dan cacian sepanjang hari ("Derita keluarga jadi mangsa keganasan rumah tangga", 2020). Selain itu, akhbar myMetro melaporkan bahawa ketika PKP, terdapat segelintir sahaja kes yang bukan kerana isu berlarutan seperti minum minuman keras bersama-sama, namun apabila mereka sudah mabuk dan hilang kawalan, tercetusnya kejadian pukul memukul kerana masing-masing telah hilang kawalan (Nawawi, 2020). Situasi sedemikian turut disokong oleh Vora et al. (2020) yang menyatakan bahawa semasa perintah berkurung, pendera mungkin menimbulkan keganasan terhadap pasangan untuk memenuhi keperluan pengambilan alkohol atau mungkin meminum alkohol di rumah di hadapan ahli keluarganya kerana kedai minuman keras ditutup. Kedua-dua senario ini menjadikan KRT bertambah buruk. Begitu juga dengan kenyataan oleh Abbey et al. (2014) dan Leonard dan Quigley (2017), iaitu pengaruh dadah dan alkohol seringkali dikaitkan dengan pendera KRT. 


\section{c. Kebergantungan pada pasangan}

Seperti yang dilaporkan dalam akhbar New Straits Times, ketika PKP, terdapat juga kes pasangan yang tidak dapat keluar mencari rezeki disebabkan oleh kehilangan pekerjaan dan terpaksa berkurung di rumah sehingga menyebabkan mereka menjadi terlalu bergantung kepada pendera dari segi kewangan dan perlindungan (Arumugam, 2020). Krisis seperti ini memberi kesan terhadap mangsa yang mana tekanan kewangan dan psikologi menyumbang kepada peningkatan kes KRT. Kehilangan sumber pendapatan dalam kalangan wanita juga menyebabkan mereka menjadi lebih terdedah dengan ancaman oleh pasangan mereka yang lebih berkuasa. Hal ini demikian kerana pendera mungkin mengawal setiap tindakan mereka kerana terperangkap di rumah sepanjang hari sehingga sukar untuk meminta bantuan. Wanita yang tidak dapat bekerja semasa PKP juga mungkin menjadi bergantung dari segi kewangan kepada pasangan pendera mereka. Perkara ini disokong oleh kajian Arthur dan Clark (2009) yang mendapati bahawa pergantungan ekonomi sebagai penyebab KRT. Wanita menjadi bergantung kepada lelaki untuk kestabilan ekonomi dan keadaan ini memberi lebih banyak kuasa dan kawalan kepada lelaki di dalam rumah tangga (Rauhaus et al., 2020). Mittal dan Singh (2020) menyatakan bahawa semasa perintah berkurung, lebih ramai wanita yang berada dalam pekerjaan informal diberhentikan dan menyebabkan mereka mengalami kesan yang lebih besar ketika mereka terpaksa bergantung kepada ekonomi pasangan lelaki mereka. Kebergantungan ekonomi ini bukan sahaja meningkatkan risiko keganasan berdasarkan jantina tetapi juga menyukarkan mereka untuk meninggalkan pendera yang mana semasa perintah berkurung, individu wanita berada dekat dengan pasangan lelaki, tidak mempunyai kebebasan untuk keluar, ketiadaan sumber kewangan, kehilangan hubungan sosial dan dikurung bersama pendera 24 jam 7 hari sehingga menyebabkan peningkatan keganasan di dalam rumah (Mittal \& Singh, 2020; Schneider et al., 2016).

\section{d. Ketiadaan sistem sokongan sosial yang kukuh}

Keterbatasan sokongan sosial telah menjadi faktor berlakunya KRT semasa PKP. Selain daripada gejala pengambilan dadah dan arak, ketiadaan sistem sokongan sosial disebabkan oleh kawalan pergerakan juga dirujuk sebagai faktor KRT yang memutuskan aktiviti perjumpaan dengan rakanrakan dan ahli keluarga. Disebabkan itu, ramai wanita telah menjadi mangsa KRT di rumah. Sumber berita BERNAMA melaporkan bahawa semasa PKP, mangsa tidak mempunyai akses atau capaian kepada talian telefon dan tidak dapat membawa diri untuk keluar rumah bagi membuat laporan polis kerana kurangnya operasi perkhidmatan pengangkutan awam (Baharin, 2020). Keterbatasan operasi sistem pengangkutan awam dan penutupan pelbagai pejabat secara tidak langsung menghalang mangsa untuk memperoleh sebarang bantuan. Mangsa yang menghabiskan masa bersama pendera di rumah berpotensi untuk menghasilkan konflik yang lebih tinggi. Menurut Bradbury-Jones dan Isham (2020), perintah berkurung yang dijalankan untuk menangani pandemik COVID-19 telah memberikan kebebasan besar kepada pendera yang mana memudahkan mereka untuk melakukan kawalan dengan menghadkan akses telefon, internet dan hubungan individu lain terhadap mangsa. Bouillon-Minois et al. (2020) juga menyatakan bahawa sekatan untuk meninggalkan rumah secara drastik menghalang kemampuan mangsa untuk meminta sebarang pertolongan. 
e. Konflik dalaman individu

Satu situasi yang dilaporkan oleh agensi berita BERNAMA, iaitu kes tragik ketika PKP melibatkan individu wanita berumur 40 tahun yang dibelasah teruk oleh suaminya. Setelah mangsa membuat laporan polis, suami tersebut yang merupakan seorang penganggur berjanji untuk berdamai semula dan menyelesaikan masalah dengan baik bersama isterinya. Namun, apabila tiba di rumah, suami tersebut menikam isteri serta bapa isterinya sebelum bertindak menggantung diri (Baharin, 2020). Selain itu, akhbar myMetro juga melaporkan bahawa kejadian KRT disebabkan punca yang pelbagai misalnya pergaduhan antara pasangan seperti cemburu, perselisihan faham berhubung perkara kecil dan perebutan hak penjagaan anak yang mana kebanyakan mereka yang terlibat dengan masalah KRT ini sudah mengalami pergaduhan dalam tempoh yang lama sebelum PKP (Nawawi, 2020). Dapat dilihat bahawa pertelagahan yang sudah lama berlaku sebelum pandemik apabila diteruskan ketika PKP akan menyebabkan impak yang lebih buruk terhadap keluarga yang terlibat dalam KRT.

\section{f. Tiada ilmu tentang KRT}

Laporan daripada Astro Awani menyatakan bahawa ketiadaan ilmu dan kesedaran untuk menguruskan konflik dan emosi merupakan punca utama kes KRT termasuk isu penderaan pasangan atau ahli keluarga ketika PKP (Razi, 2020). KRT bukan merujuk kepada penderaan fizikal sahaja, malah kata-kata yang menyakitkan hati, kemarahan dan maki hamun juga memberi kesan secara langsung kepada masyarakat. Menurut Abdullah (2006), beliau menyatakan bahawa penting untuk memberi kesedaran dan pengetahuan tentang undang-undang KRT kepada masyarakat. Hal ini adalah mustahak kerana ramai melihat KRT sebagai sesuatu yang bukan menjadi kesalahan jenayah dan mereka berpandangan bahawa KRT hanyalah masalah keluarga semata-mata. Perlu diambil maklum bahawa negara Malaysia telah mengiktiraf KRT sebagai satu jenayah besar di bawah kanun keseksaan dan boleh disabitkan kesalahan kepada si pendera (Isaacs et al., 2019). Isaacs et al. (2019) juga menyatakan bahawa kefahaman masyarakat tentang KRT masih kurang dan perlu dididik berhubung hak-hak mereka oleh pihak yang bertanggungjawab bagi memastikan masalah KRT dapat diselesaikan secara berperingkat. Campbell (2020) menekankan bahawa memperluaskan perkongsian masyarakat dan menyebarkan kesedaran tentang pentingnya melaporkan kejadian penderaan adalah sangat penting untuk mengurangkan bilangan kes tersebut. Akhbar Sinar Harian juga melaporkan bahawa mangsa KRT tidak perlu takut untuk keluar rumah bagi mendapatkan bantuan atau perlindungan sekiranya hak atau keselamatan diri mereka diancam ketika PKP (Ramli, 2020).

\section{Peranan pihak pemegang taruh ketika PKP}

Pelbagai pihak pemegang taruh yang mengambil inisiatif penting untuk mengumpulkan maklumat, memberikan bimbingan dan meningkatkan kesedaran tentang kes yang berlaku terhadap wanita ketika pandemik (Kumar, 2020). Terdapat agensi kerajaan dan pertubuhan bukan kerajaan (NGO) yang melaporkan bahawa mereka menerima lebih banyak panggilan berhubung KRT ketika pandemik berbanding tempoh bukan pandemik (Konikkara, 2020). Pandemik ini telah menunjukkan bahawa banyak perkara yang perlu dilakukan untuk memastikan individu yang 
mengalami penderaan dapat memperoleh akses kepada sokongan, perlindungan, dan perkhidmatan rawatan perubatan (Evans et al., 2020).

Di Malaysia, terdapat beberapa organisasi yang memainkan peranan dalam isu KRT yang berlaku sepanjang PKP. Misalnya, akhbar New Straits Times melaporkan bahawa kerajaan negeri Pulau Pinang telah memperuntukkan wang sebanyak RM100,000 untuk mengekang isu KRT semasa tempoh PKP (Dermawan, 2020). Usaha tersebut dilakukan setelah melihat 33 kes yang diterima oleh Pusat Kesedaran Wanita (WCC) sejak PKP dilaksanakan. Peruntukan tersebut diagihkan kepada NGO seperti Pusat Kesedaran Wanita (WCC) dan Sneham Malaysia di Pulau Pinang untuk meneruskan usaha mereka dalam memberi kesedaran serta mencegah KRT. Peruntukan tersebut adalah terbuka kepada semua NGO termasuk persatuan melibatkan agama yang dapat memberikan khidmat kaunseling, intervensi, bantuan 24 jam dan tempat perlindungan kecemasan kepada mangsa-mangsa KRT. Pulau Pinang juga merupakan negeri pertama yang memberikan bantuan sedemikian untuk membendung isu KRT ketika PKP (Lee, 2020).

Selain itu, BERNAMA melaporkan bahawa agensi kerajaan seperti Kementerian Pembangunan Wanita, Keluarga dan Masyarakat (KPWKM) dan Jabatan Kemajuan Islam Malaysia (JAKIM) serta NGO seperti Pertubuhan Pertolongan Wanita (WAO), Love Yourself Association dan Befrienders Kuala Lumpur masing-masing memainkan peranan dalam menyalurkan bantuan dalam bentuk sokongan emosi, kaunseling, khidmat nasihat, bimbingan, terapi emosi dan kerohanian dengan matlamat untuk memberi sinar baharu kepada kehidupan mangsa (Baharin, 2020). Akhbar The Malaysian Insight (2020) melaporkan bahawa WAO merupakan sebuah NGO yang menyediakan perkhidmatan kaunseling dan sokongan krisis secara percuma kepada wanita dan kanak-kanak yang mengalami penderaan. WAO juga sedang menguruskan rumah perlindungan KRT terbesar di Malaysia, namun rumah perlindungan tersebut kini berada pada kapasiti yang terhad. Terdapat ramai mangsa yang telah menghubungi WAO untuk mendapatkan perlindungan namun WAO tidak mempunyai keupayaan untuk menempatkan mereka di mana-mana setakat ini.

Menurut Ali dan Rashid (2020), terdapat saluran bantuan seperti talian khusus yang telah diwujudkan oleh KPWKM yang diselaraskan oleh Majlis Keselamatan Negara (MKN). Talian khas kaunseling COVID-19 juga diwujudkan dengan melibatkan hampir 900 kaunselor berdaftar di bawah Lembaga Kaunselor Malaysia (LKM) bagi menyalurkan bantuan sokongan psikososial kepada mangsa, waris mangsa, pekerja pusat kuarantin, pekerja hospital dan orang awam yang terkesan dengan pandemik dan PKP. Tambahan pula, seramai 200 pegawai psikologi Kementerian Kesihatan Malaysia (KKM) yang menganggotai Persatuan Profesion Psikologi Kementerian Kesihatan Malaysia (PsiKEM) menyalurkan bantuan dalam bentuk medium Telegram bagi menyebarkan maklumat tentang penjagaan kesihatan mental yang mana pelbagai infografik yang berguna disediakan untuk dijadikan panduan.

Akhbar MalayMail melaporkan bahawa Pusat Kesedaran Wanita (WCC) menyediakan perkhidmatan kaunseling kritikal melalui talian hotline untuk mangsa KRT atau penderaan seksual sepanjang PKP (Mok, 2020). WCC berperanan untuk meningkatkan kesedaran berhubung perkhidmatan kaunseling sehingga mangsa KRT dapat menghubungi mereka untuk mendapatkan bantuan. Selain itu, sepanjang tempoh PKP, WCC menerusi laman sesawang Facebook rasminya juga melaporkan bahawa mereka telah melaksanakan pelbagai program kesedaran secara dalam talian seperti WCC Tamil Webinar One: A Survivor's Voice, WCC Tamil Webinar Two: How To Get Help, WCC Tamil Webinar Three: The Way Forward, Keharmonian Keluarga Tanggungjawab Bersama, dan Gangguan Seksual Ke Atas Wanita: Apa Wanita Perlu Tahu (Facebook rasmi WCC, 2020). Program-program ini diadakan secara percuma menerusi atas talian 
untuk memberi kesedaran kepada golongan wanita supaya lebih cakna dengan isu-isu sosial yang berlaku terutama semasa PKP. Di samping itu, WCC juga telah mencipta dan memuat naik lebih daripada 60 poster secara atas talian berkaitan pelbagai isu dalam Bahasa Melayu, Inggeris dan Cina untuk meningkatkan kesedaran dan membantu anak-anak, ibu bapa dan keluarga bagi mengatasi tekanan semasa pandemik COVID-19 (WCC, 2020).

Di samping itu, Pertubuhan Pertolongan Wanita (WAO) memainkan peranannya berhubung kes KRT yang berlaku ketika PKP. WAO bergiat aktif dalam mempromosikan langkah atau strategi terhadap mangsa KRT untuk bertindak dengan sewajarnya bagi mengelakkan diri daripada situasi KRT semasa PKP melalui poster-poster yang dimuat naik dalam laman sesawang rasmi Facebook mereka, menyediakan khidmat kaunseling, khidmat panggilan untuk kes-kes berhubung KRT 24 jam, menyediakan tempat perlindungan kepada mangsa serta makanan dan minuman percuma. WAO juga telah menjalankan beberapa siri seminar dalam talian sepanjang PKP bersama penceramah dari WAO, pensyarah universiti dan agensi luar yang bertauliah untuk memberikan pendedahan dan kesedaran kepada masyarakat berhubung isu KRT. Antara seminar yang dijalankan oleh WAO adalah Rasa Selamat di Rumah? yang mempunyai empat siri, iaitu (i) Kenali: Oh, Macam Itu Rupanya Keganasan Dalam Keluarga?, (ii) Kendali: Bila Ada Keganasan Dalam Keluarga, Kita Nak Buat Apa Ya?, (iii) Kaitkan: Siapa Lagi Yang Patut Tolong Bila Ada Keganasan Dalam Keluarga? dan (iv) Tempat Selamat: Kita Semua Ada Hak Untuk Bebas Dari Keganasan (Facebook rasmi WAO, 2020).

Justeru, dapat dilihat bahawa terdapat beberapa pihak pemegang taruh yang melaksanakan tanggungjawab untuk menyalurkan bantuan kepada mangsa-mangsa KRT terutama wanita semasa PKP dari segi kewangan, perlindungan, kempen, dan kaunseling. Ia secara tidak langsung menunjukkan bahawa masih terdapat pihak pemegang taruh yang cakna dengan isu KRT yang berlaku dalam masyarakat ketika berhadapan dengan situasi PKP dan pandemik COVID-19.

\section{Kesimpulan dan cadangan}

Sebagai rumusan, walaupun pelaksanaan PKP adalah baik untuk mengawal dan memutuskan rantaian pandemik COVID-19, namun ia secara tidak langsung telah membuktikan bahawa wujudnya isu sosial lain seperti insiden KRT. Kajian ini berjaya membongkar enam faktor penyumbang kepada isu KRT ketika PKP dilaksanakan dalam negara serta peranan pihak pemegang taruh dalam membantu menyelesaikan isu ini. Kajian ini juga ingin mencadangkan beberapa strategi yang sesuai untuk dilaksanakan bagi membendung isu KRT semasa PKP.

Strategi yang pertama adalah melibatkan mangsa. Seperti yang sedia maklum, mangsa sememangnya tidak berupaya untuk melawan pendera semasa berada dalam rumah disebabkan oleh pelbagai halangan dan kesulitan. Namun apa yang boleh dilakukan oleh mangsa untuk menjamin keselamatan mereka adalah; (i) memiliki kunci rumah pendua untuk simpanan sendiri, (ii) memastikan ahli keluarga atau rakan yang paling dipercayai mempunyai kunci rumah untuk membawa mangsa keluar sekiranya dikurung dan didera oleh pasangan, (iii) mangsa perlu menyimpan nombor telefon individu yang penting selain di telefon bimbit untuk dihubungi sekiranya berlaku krisis KRT, dan (iv) mangsa juga perlu menyediakan sebarang bentuk amaran KRT yang dapat dilihat oleh jiran-jiran supaya mereka dapat mengambil maklum dengan keadaan tersebut. Strategi yang kedua adalah melibatkan orang awam. Strategi ini menuntut orang awam untuk sentiasa peka dengan keadaan kejiranan di sekeliling. Misalnya apabila terdengar pergaduhan atau mengesyaki sebarang kes KRT yang berlaku di dalam kejiranan mereka, orang awam haruslah menghubungi pihak berkuasa dengan pantas untuk tindakan selanjutnya yang mana 
mampu menyelamatkan nyawa dan jiwa mangsa. Strategi yang ketiga adalah melibatkan pihak kerajaan. Pihak kerajaan perlulah menyediakan banyak bantuan berupa kewangan kepada rakyat yang bukan berbentuk one-off sahaja. Hal ini demikian kerana, krisis sosial yang berlaku sepanjang pandemik secara dominannya melibatkan faktor ekonomi. Ramai rakyat yang hilang pekerjaan dan sumber kewangan sehingga mengakibatkan tekanan dalam hidup mereka yang secara tidak langsung mewujudkan isu KRT. Bantuan kewangan sepanjang PKP dirujuk sangat penting untuk kesihatan mental dan emosi individu yang terkesan dengan masalah ekonomi. Pihak kerajaan juga perlu menyalurkan lebih banyak dana kewangan kepada NGO yang khusus mengendalikan kes KRT supaya mereka dapat menjalankan usaha-usaha untuk membendung isu ini dengan lebih holistik terutamanya dalam menyediakan tempat perlindungan untuk mangsa KRT yang dirujuk semakin terhad kapasitinya semasa PKP.

Diharapkan agar kajian ini dapat membantu pelbagai pihak pemegang taruh untuk lebih cakna dan bergiat aktif dalam menyalurkan bantuan menyelesaikan isu ini disebabkan oleh tempoh PKP di negara masih diteruskan. Hal ini demikian kerana, kemungkinan akan wujud lebih banyak isu KRT yang berlaku dalam kalangan wanita sepanjang tempoh PKP dipanjangkan. Walau bagaimanapun, kajian berhubung KRT dalam konteks pandemik COVID-19 dan PKP masih terhad dijalankan di Malaysia. Semoga kajian ini akan dapat memberi pendedahan dan manfaat kepada pihak pemegang taruh dan ahli-ahli akademik untuk menjalankan kajian sebegini seterusnya dalam skop dan konteks yang lebih luas.

\section{Penghargaan}

Penulis merakamkan setinggi-tinggi penghargaan kepada Universiti Sains Malaysia dan Kementerian Pendidikan Malaysia yang telah membiayai kajian ini melalui geran penyelidikan fundamental FRGS (203/PHUMANITI/6711647) yang bertajuk A Socio-Ecological Approach to Examining Health Behavior and Health Equity in Urban Areas of Malaysia.

\section{Rujukan}

Abbey, A., Wegner, R., Woerner, J., Pegram, S.E., \& Pierce, J. (2014). Review of survey and experimental research that examines the relationship between alcohol consumption and men's sexual aggression perpetration. Trauma, Violence \& Abuse, 15(4), 265-282.

Abdullah, N.A. (2006). Peranan undang-undang keluarga ke arah pencegahan keganasan rumah tangga: Akta keganasan rumah tangga 1994. Fakulti Undang-Undang: Universiti Malaya.

Agüero, J.M. (2020). COVID-19 and the rise of intimate partner violence. World Development, 137, 1-7.

Ali, E., \& Rashid, M.A. (2020). Pandemik COVID-19: Mendepani impak psikososial. Perspektif, 11/2020. Penerbit Terengganu Strategic \& Integrity Institute (TSIS).

Arthur, C., \& Clark, R. (2009). Determinants of domestic violence: a cross-national study. International Journal of Sociology of the Family, 35(2), 147-67.

Arumugam, T. (2020, April 04). MCO-linked domestic violence rises. New Straits Times. https://www.nst.com.my/news/exclusive/2020/04/581233/mco-linked-domestic-violencerises 
Baharin, M.F. (2020, Mei 20). Kisah duka dan derita isteri di sebalik tabir PKP. BERNAMA. https://www.bernama.com/bm/am/news_covid-19.php?id=1843404

Boserup, B., McKenney, M., \& Elkbuli, A. (2020). Alarming trends in US domestic violence during the COVID-19 pandemic. The American Journal of Emergency Medicine, 38(12), $1-3$.

Bouillon-Minois, J.B., Clinchamps, M., \& Dutheil, F. (2020). Coronavirus and quarantine: Catalysts of domestic violence. Violence Against Women, 1-3. https://doi.org/10.1177/1077801220935194

Bradbury-Jones R.N.C., \& Isham, L. (2020). The pandemic paradox: The consequences of COVID-19 on domestic violence. Journal of Clinical Nursing, 29(13-14), 2047-2049.

Brooks, S.K., Webster, R.K., Smith, L.E., Woodland, L., Wessely, S., Greenberg, N., \& Rubin, G.J. (2020). The psychological impact of quarantine and how to reduce it: quick review of the evidence. The Lancet, 395(10227), 912-920.

Burgen, S. (2020, April 28). Women killed in Spain as coronavirus lockdown sees rise in domestic violence. The Guardian. https://www.theguardian.com/global-development/2020/apr/28/ three-women-killed-in-spain-as-coronavirus-lockdown-sees-rise-in-domestic-violence

Campbell, A.M. (2020). An increasing risk of family violence during COVID-19 pandemic: Strengthening community collaborations to save lives. Forensic Science International: Reports, 2, 1-3.

Das, M., Das, A., \& Mandal, A. (2020). Examining the impact of lockdown (due to COVID-19) on Domestic Violence (DV): An evidences from India. Asian Journal of Psychiatry, 54, 12.

Dawood, S.R.S., Ramli, M.W., \& Som, S.H.M. (2020). Daya tahan warga emas dalam era pandemik: Satu tinjauan awal sewaktu perintah kawalan pergerakan (PKP) di Pulau Pinang, Malaysia. GEOGRAFI, 8(2), 110-128.

Derita keluarga jadi mangsa keganasan rumah tangga. (2020, Jun 02). Sinar Harian. https://www.sinarharian.com.my/article/85914/BERITA/Jenayah/Derita-keluarga-jadimangsa-keganasan-rumah-tangga

Dermawan, A. (2020, April 24). MCO: Penang allots RM100k for NGOs dealing with domestic violence. New Straits Times. https:/www.nst.com.my/news/nation/2020/04/587165/mcopenang-allots-rm100k-ngos-dealing-domestic-violence

Ertan, D., El-Hage, W., Thierrée, S., Javelot, H., \& Hingray, C. (2020). COVID-19: Urgency for distancing from domestic violence. European Journal of Psychotraumatology, 11(1), 1-7.

Evans, M.L., Lindauer, M., \& Farrell, M.E. (2020). A pandemic within a pandemic - intimate partner violence during Covid-19. The New England Journal of Medicine, 383(24), 23022304.

Facebook rasmi Pertubuhan Pertolongan Wanita (WAO). (2020). https://web.facebook.com/womens.aid.org/photos/?ref=page_internal

Facebook rasmi Women's Centre for Change (WCC). (2020). https://web.facebook.com/wccpenang/events/?ref=page_internal

Flury, M., Nyberg, E., \& Rossler, A.R. (2010). Domestic violence against women: Definitions, epidemiology, risk factors and consequences. Swiss Medical Weekly, 140, 1-6.

Gani, F.A. (2020, April 03). Mengapa kes keganasan rumah tangga meningkat semasa PKP?. Astro Awani. $\quad$ https://www.astroawani.com/berita-malaysia/mengapa-kes-keganasan-rumahtangga-meningkat-semasa-pkp-236528 
Goh, K.K., Lu, M.L., \& Jou, S. (2020). Impact of COVID-19 pandemic: Social distancing and the vulnerability to domestic violence. Psychiatry and Clinical Neurosciences, 74(11), 1-2.

Hamid, H.A. (2020, Mac 25). Keganasan rumah tangga boleh berlaku ketika perintah kawalan pergerakan - PPWS. Utusan Borneo. https://www.utusanborneo.com.my/2020/03/25/ keganasan-rumah-tangga-boleh-berlaku-ketika-perintah-kawalan-pergerakan-ppws

Hamid, M.N.S., Ali, R.M., \& Ramli, M.W. (2021). Impak perintah kawalan pergerakan terhadap golongan miskin: Satu analisis cerpen "Kuncitara". Malaysian Journal of Social Sciences and Humanities, 6(2), 1-8.

Isaacs, V., Mohamad, N., Adnan, L.H.M., Rosdi, W.H.A.W., Mustafa, N.S., Fauzi, N.F.A.M., \& Zakaria, N.H. (2019). Hubungan antara penagihan dadah dengan keganasan rumah tangga. Jurnal Undang-Undang dan Masyarakat, 25, 7-14.

Ismail, T.A.T., \& Sulaiman, Z. (2020, Jun 24). Kesejahteraan rumah tangga semasa perintah kawalan pergerakan. Pusat Sumber Komunikasi Risiko dan Media COVID-19 Universiti Sains Malaysia. http://covid19.kk.usm.my/index.php/artikel/bacaan-umum/30kesejahteraan-rumah-tangga-semasa-perintah-kawalan-pergerakan

Jabatan Kebajikan Masyarakat. (2020). Pengenalan keganasan rumah tangga. http://www.jkm.gov.my/jkm/index.php?r=portal/left\&id=TU01WHptUlFnbDEyT0Z5OC tsVjh4QT09

Johnston, K. (2020, April 12). Covid 19 coronavirus: Domestic violence is the second, silent epidemic amid lockdown. New Zealand Media and Entertainment. https://www.nzherald.co.nz/nz/covid-19-coronavirus-domestic-violence-is-the-secondsilent-epidemic-amid-lockdown/5ZUPUGT2MBITLISTC4RVGOCK24/

Kagi, J. (2020). Crime rate in WA plunges amid coronavirus social distancing lockdown measures. ABC News Australia. https://www.abc.net.au/news/2020-04-08/coronavirus-shutdownsees-crime-rate-drop-in-wa/12132410

Kementerian Pembangunan Wanita Keluarga dan Masyarakat (KPWKM). (2020, Julai 27). Pemberitahuan pertanyaan jawab lisan Dewan Rakyat mesyuarat kedua, penggal ketiga parlimen keempat belas. https://www.kpwkm.gov.my/kpwkm/uploads/files/Dokumen/ Jawapan\%20Dewan\%20Rakyat/Gabung\%2027\%20Julai\%202020.pdf

Kofman, Y.B., \& Garfin, D.R. (2020). Home is not always a haven: The domestic violence crisis amid the COVID-19 pandemic. Psychological Trauma: Theory, Research, Practice, and Policy, 12(1), 199-201.

Konikkara, A. (2020, April 15). Lockdown and domestic violence: As NGOs struggle to support women at risk, government plays catch up. The Carawan-A Journal of Politics \& Culture. https://caravanmagazine.in/gender/lockdown-domestic-violence-ngo-strugglegovernment-catch-up

Kumar, A. (2020). COVID-19 and domestic violence: A possible public health crisis. Journal of Health Management, 22(2), 192-196.

Lee, E. (2020, Mei 19). NGOs hail state's RM100,000 allocation to deal with domestic violence. Buletin Mutiara. https://www.buletinmutiara.com/ngos-hail-states-rm100000-allocationto-deal-with-domestic-violence/

Leonard, K.E., \& Quigley, B.M. (2017). Thirty years of research show alcohol to be a cause of intimate partner violence: Future research needs to identify who to treat and how to treat them. Drug and Alcohol Review, 36(1), 7-9. 
Lepla, L. (2020, Mac 26). Victims of domestic violence are seeking a way out of the corona crisis. Mondiaal Nieuws. https://www.mo.be/nieuws/stijgt-huishoudelijk-geweld-doorverstrengde-maatregelen

Liu, W., Yue, X.G., \& Tchounwou, P.B. (2020). Response to the COVID-19 epidemic: The Chinese experience and implications for other countries. International Journal of Environmental Research and Public Health, 17(7), 1-6.

Malik, S., \& Naeem, K. (2020). Impact of COVID-19 pandemic on women: Health, livelihoods \& domestic violence. Sustainable Development Policy Institute. https://think-asia.org/ handle/11540/11907

Mazza, M., Marano, G., Lai, C., Janiri, L., \& Sani, G. (2020). Danger in danger: Interpersonal violence during COVID-19 quarantine. Psychiatry Research, 289, 1-3.

Mittal, S., \& Singh, T. (2020). Gender-based violence during COVID-19 pandemic: A minireview. Frontiers in Global Women's Health, 1(4), 1-7.

Mok, O. (2020, Mac 26). Women's Centre for Change's online counselling for women, children in crisis continues. MalayMail. https://www.malaymail.com/news/malaysia/2020/03/26/ womens-centre-for-changes-online-counselling-for-women-children-in-crisis-c/1850452

Na'aim, M.S.M., Rajamanickam, R., \& Nordin, R. (2019). Female victims of domestic violence and their rights to compensation in Malaysia. Journal of Nusantara Studies, 4(1), 384-400.

Nawawi, M.H. (2020, April 17). PKP: 353 kes keganasan rumah tangga dilaporkan. myMetro. https://www.hmetro.com.my/mutakhir/2020/04/567642/pkp-353-kes-keganasan-rumahtangga-dilaporkan

Perez-Vincent, S.M., Carreras, E., Gibbons, M.A., Murphy, T.E., \& Rossi, M.A. (2020). COVID19 lockdowns and domestic violence: Evidence from two studies in Argentina. InterAmerican Development Bank: Washington, DC, USA.

Power, K. (2020). The COVID-19 pandemic has increased the care burden of women and families. Sustainability: Science, Practice and Policy, 16(1), 67-73.

Pusat Kesedaran Wanita (WCC). (2020). Newslink: Half Yearly Newsletter January-June 2020. http://wccpenang.org/01important/newslink/Newslink\%20Jan_Jun2020-1.pdf

Ramli, M.A. (2020, April 21). Keganasan rumah tangga: Jangan takut lapor polis! Sinar Harian. https://www.sinarharian.com.my/article/79942/BERITA/Nasional/Keganasan-rumahtangga-Jangan-takut-lapor-polis

Ramli, M.W., \& Jamri, M.H. (2021). The impact of COVID-19 pandemic: A closer look at the night market traders' experience in Penang, Malaysia. International Journal of Academic Research in Business \& Social Sciences, 11(1), 741-760.

Rauhaus, B.M., Sibila, D., \& Johnson, A.F. (2020). Addressing the increase of domestic violence and abuse during the COVID-19 pandemic: A need for empathy, care, and social equity in collaborative planning and responses. The American Review of Public Administration, 50(6-7), 668-674.

Razi, F.D. (2020, April 22). Tiada ilmu urus konflik, punca kes keganasan rumah tangga Perunding. Astro Awani. https://www.astroawani.com/berita-malaysia/tiada-ilmu-uruskonflik-punca-kes-keganasan-rumah-tangga-perunding-239512

Schneider, D., Harknett, K., \& McLanahan, S. (2016). Intimate partner violence in the great recession. Demography, 53(2), 471-505.

Silverio-Murillo, A., Balmori de la Miyar, J.R., \& Hoehn-Velasco, L. (2020). Families under confinement: COVID-19, domestic violence, and alcohol consumption. Andrew Young 
School of Policy Studies Research Paper Series Forthcoming. http://dx.doi.org/10.2139/ssrn.3688384

The Malaysian Insight. (2020, April 14). 6 langkah lindungi mangsa keganasan rumah tangga sepanjang PKP. https://www.themalaysianinsight.com/bahasa/s/237407

UN Women. (2020a). COVID-19 and ending violence against women and girls. https://www.unwomen.org/-

/media/headquarters/attachments/sections/library/publications/2020/issue-brief-covid-19and-ending-violence-against-women-and-girls-en.pdf?la=en \&vs=5006

UN Women. (2020b). Violence against women and girls: The shadow pandemic. https://www.unwomen.org/en/news/in-focus/in-focus-gender-equality-in-covid-19response/violence-against-women-during-covid-19

United Nations. (2020a). What is domestic abuse? https://www.un.org/en/coronavirus/what-isdomestic-abuse

United Nations. (2020b, April 06). UN chief calls for domestic violence 'ceasefire' amid 'horrifying global surge'. UN News. https://news.un.org/en/story/2020/04/1061052

Vincent, C. (2020, March 30). COVID-19 and domestic violence: Another Public Health Emergency. Socialist Alternative. https://www.socialistalternative.net/2020/03/30/covid19-and-domestic-violence-another-public-health-emergency/

Vora, M., Malathesh, B.C., Das, S., \& Chatterjee, S.S. (2020). COVID-19 and domestic violence against women. Asian Journal of Psychiatry, 53, 1-2.

World Health Organization. (2017, November 29). Violence against women. https://www.who.int/news-room/fact-sheets/detail/violence-against-women

World Health Organization. (2020a). COVID-19 and violence against women: What the health sector/system can do. https://apps.who.int/iris/bitstream/handle/10665/331699/WHOSRH-20.04-eng.pdf?ua=1

World Health Organization. (2020b). Levels of domestic violence increase globally, including in the region, as COVID-19 pandemic escalates. http://www.emro.who.int/violence-injuriesdisabilities/violence-news/levels-of-domestic-violence-increase-as-covid-19-pandemicescalates.html

World Health Organization. (2020c, April 04). Media briefing on \#COVID-19 with @DrTedros. WHO Official Twitter. https://twitter.com/WHO/status/1246112597897875456 